*Mestranda em Direito pela Universidade Federal da Paraíba. Bacharela em Direito pela mesma instituição (2016), com desenvolvimento de pesquisas científicas na temática de gênero e direito (2012 a 2014). Participou do grupo de pesquisa Gênero e Direito - UFPB (2014), vinculado ao $\mathrm{CNPq}$. Áreas de atuação e interesse: Direitos Humanos, Direito Penal, Filosofia Jurídica, Sociologia Jurídica e Direito Constitucional.

E-mail: thaise_rds@hotmail.com

** Doutor e Mestre em Direito Penal pela Universitat de València - Espanha (20022006); Especialização em Direito Empresarial pela Universidade Federal da Paraíba - UFPB (1998); Graduado em Direito pelo Centro Universitário de João Pessoa - UNIPE (1995); Coordenador Acadêmico do Mestrado em Direito e Desenvolvimento do Centro Universitário de João Pessoa UNIPÉ; Professor de Direito Penal da Universidade Federal da Paraíba (UFPB); Professor Permanente do Programa de Mestrado e Doutorado em Direito da mesma instituição; Professor de Informática Jurídica do Centro Universitário denJoão Pessoa - UNIPÊ. Advogado e sócio do Escritório Rabay, Bastos \& Palitot.

E-mail: romulo.palitot@uv.es

**Mestranda no Programa de PósGraduação em Direitos Humanos na Universidade Federal da Paraíba. Juíza de Direito do Poder Judiciário da Paraíba. Membro da Comissão de Segurança do Tribunal de Justiça da Paraíba, na qualidade de magistrada representante da Região Integrada de Segurança Pública (REISP). Coordenadora da Escola Superior da Magistratura-ESMA, em Campina Grande e docente da mesma instituição, no Curso de Preparação à Carreira de Magistrado (CPM), ministrando a disciplina de Direito Penal II e Práticas Criminais.

E-mail: christinapenazzi@gmail. com

\section{Controle de Convencionalidade da Lei de Anistia No 6.683/79: Direito À MEMÓria e À VERDAde}

\author{
CONVENTIONALITY CONTROL OF AMNESTY LAW \\ $\mathrm{N}^{\circ}$ 6.683/79: RIGHT TO MEMORY AND TRUTH
}

\section{Thaise Silva Rodrigues* Romulo Rhemo Palitot Braga** Ana Christina Soares Penazzi Coelho***}

Como citar: RODRIGUES, Thaise Silva; BRAGA, Romulo Rhemo Palitot; COELHO; Ana Christina Soares Penazzi. Controle de convencionalidade da Lei de Anistia $n^{\circ}$ 6.683/79: Direito à memória e à verdade. Revista do Direito Público, Londrina, v. 14, n. 3, p. 131-149, dez. 2019. DOI: 10.5433/24157-108104-1.2019v14n3p. 131. ISSN: 1980-511X

Resumo: No presente trabalho é abordada a importância do controle de convencionalidade para a preservação da unidade do sistema jurídico brasileiro e para o controle de validade dos atos normativos internos com respeito aos direitos humanos. Parte-se da análise da lei de anistia $n^{\circ} 6.683 / 79$, a qual vem servindo de obstáculo para a investigação dos fatos e para a identificação e punição dos responsáveis pelas atrocidades ocorridas durante a fase do regime militar no país. Conclui-se pela incompatibilidade da lei de anistia $n^{\circ}$ 6.683/79 frente à Convenção Americana sobre Direitos Humanos, a qual integra o ordenamento jurídico brasileiro. A lei de anistia não passou imune ao duplo controle de validade dos atos normativos estatais, por ter sido declarada inconvencional em sentença da Corte Interamericana de Direitos Humanos no caso Gomes Lund, devendo, por conseguinte, ser declarada inválida também pela Justiça brasileira.

Palavras-chave: Controle de Convencionalidade. Lei de anistia. Direito à memória e à verdade. Crimes contra a humanidade. Corte Interamericana de Direitos Humanos.

Abstract: This paper discusses the importance of conventionality control for the unity of the Brazilian legal system and for the validity of internal normative acts set in accordance with human rights. Unfortunately, Amnesty Law no. 6683/79 has served as an obstacle for the investigation of past human rights atrocities 
in Brazil's military dictatorship past and the identification and punishment of those responsible for it. This paper concludes that this law is incompatible with the American Convention on Human Rights, which is an important part of the Brazilian legal system. Moreover, this law is not immune to the double control of the validity of state normative acts, because it was declared inconvenient in a ruling of the Inter-American Court of Human Rights in the Gomes Lund case, and should therefore be declared invalid by Brazilian courts.

Keywords: Conventionality Control. Amnesty law. Right to memory and of truth. Crimes against humanity. Inter-American Court of Human Rights. 


\section{INTRODUÇÃO}

A região latino-americana é marcada por extrema desigualdade social e com democracias ainda em fase de consolidação. O legado deixado pelo período ditatorial foi de uma cultura de impunidade e violência que marcam até hoje esse setor.

Por essa razão é que, tanto do ponto de vista moral, como do ponto de vista jurídico, é inadmissível que as atrocidades e perseguições cometidos nesse período possam permanecer encobertas por leis de anistia, perpetuando a impunidade e relegando ao esquecimento e ao desconhecimento pelo povo de sua própria história. É preciso que os cidadãos conheçam a verdade, direito de todos, para possibilitar o amadurecimento das instituições democráticas de modo a evitar que o passado se repita.

Neste trabalho é abordada a importância do controle de convencionalidade para a preservação da unidade do sistema jurídico brasileiro e para o controle de validade dos atos normativos, de modo a assegurar o respeito pelos tratados de direitos humanos incorporados pelo Estado, em especial, para a preservação dos direitos fundamentais à memória e à verdade histórica.

$\mathrm{O}$ instituto do controle de convencionalidade consiste em averiguar a compatibilidade entre um ato normativo interno de um Estado e as obrigações por ele assumidas em tratados ou convenções internacionais em matéria de proteção dos direitos humanos.

No universo jurídico brasileiro, esse método de controle tem ganhado espaço após a edição da Emenda Constitucional 45/2004, a qual conferiu status hierárquico superior aos tratados que versam sobre direitos humanos aos quais o Brasil aderir, firmando, assim, novo parâmetro de validade da produção normativa nacional.

Devido a isso, a lei de anistia $\mathrm{n}^{\circ} 6.683 / 79$, que havia sido recepcionada pela nova ordem jurídica pátria quando do julgamento da Arguição de Descumprimento de Preceito Fundamental (ADPF) 153/DF, decidida pelo Supremo Tribunal Federal no ano de 2010, entra novamente em discussão, em face agora da Convenção Americana sobre Direitos Humanos. Isto porque a lei de anistia confere o autoperdão aos responsáveis pela prática de crimes ocorridos no período da ditadura militar, impedindo, assim, a investigação e a sanção a graves violações de direitos humanos, medidas incompatíveis com a Convenção Americana (COMISSÃO INTERAMERICANA DE DIREITOS HUMANOS, 1969).

Cumpre destacar os reflexos diretos desse novo instituto para o Direito Constitucional, pois no controle de convencionalidade se adotam os tratados de direitos humanos como parâmetro de controle, e não o texto da Constituição, ou seja, todo o ordenamento jurídico deve ser compatível com os tratados de direitos humanos. Além disso, o controle de convencionalidade permite ao Supremo Tribunal Federal rever suas decisões sobre a validade de atos normativos sob o prisma de novos referenciais, ampliando, assim, a matéria afeta à sua competência.

O escopo maior deste texto é, por conseguinte, o de analisar o modo pelo qual a Constituição da República Federativa do Brasil de 1988 (BRASIL, 1988) e as instituições de 
Justiça se relacionam com o aparato internacional de proteção dos direitos humanos. Assim, é possível averiguar o modo pelo qual o sistema internacional de proteção dos direitos humanos contribui para a implementação de direitos fundamentais no panorama brasileiro.

\section{CONTROLE DE CONVENCIONALIDADE NO ORDENAMENTO JURÍDICO BRASILEIRO}

O controle da convencionalidade representa um ponto de grande complexidade nas discussões jurídicas atuais, sendo uma matéria relativamente nova na prática do direito brasileiro. É fato que, no Brasil, nunca antes se aprofundaram as discussões acerca desse tema, tendo sido essa nomenclatura (controle de convencionalidade) introduzida a pouco em nosso vocabulário jurídico.

Hoje, com a evolução jurisprudencial e doutrinária, podemos dizer que o controle de convencionalidade é uma realidade em todo Estado de Direito que tenha se inserido minimamente no mundo globalizado, e isso, obviamente, inclui o Brasil.

Piovesan (2012, p. 68-69) explicita bem essa mudança ao demonstrar que, antes da difusão do controle de convencionalidade, a cultura jurídica latino-americana era baseada em um paradigma jurídico fundado exclusivamente no sistema piramidal proposto por Hans Kelsen, sendo um modelo autorreferencial, hermético e com ênfase no ângulo interno. Entretanto, nas últimas décadas, ocorreu a substituição por um novo paradigma jurídico, com três características essenciais:

a. o trapézio, com a Constituição e os tratados internacionais de direitos humanos no ápice da ordem jurídica (com repúdio a um sistema jurídico endógeno e autorreferencial) (PIOVESAN, 2012, p. 69).

b. a crescente abertura do Direito, marcado pelo diálogo do ângulo interno com o ângulo externo (há a permeabilidade do Direito mediante o diálogo entre jurisdições; empréstimos constitucionais; e a interdisciplinariedade, a fomentar o diálogo do Direito com outros saberes e diversos atores sociais, ressignificando, assim, a experiência jurídica (PIOVESAN, 2012, p. 70).

c. o human rights approach (human centered approach), colocando no centro do sistema os conceitos de soberania popular e de segurança cidadã, estruturais e fundamentais no âmbito interno (PIOVESAN, 2012, p. 71).

As constituições latino-americanas vêm expandindo seu bloco de constitucionalidade, por meio de termos jurídicos abertos e indeterminados que ensejam uma abertura para a integração entre a ordem constitucional e a ordem internacional.

A nova estrutura hierárquica das normas jurídicas visa a incluir os tratados e convenções internacionais ratificados por determinado Estado dentro do rol de normas cogentes e de eficácia imediata. No Brasil, o Supremo Tribunal Federal (STF) tem se posicionado no sentido de não mais considerar os acordos internacionais de direitos humanos apenas como mero norte interpretativo (quando não aprovados pelo regime da Emenda Constitucional 45/2004), mas lhes dando caráter supralegal, ou seja, servem de fundamento de validade do próprio ordenamento jurídico interno: 
A nova posição prevalecente no STF foi capitaneada pelo Min. Gilmar Mendes, que, retomando a visão pioneira de Sepúlveda Pertence (em seu voto no HC 79.785/RJ15) sustentou que os tratados internacionais de Direitos Humanos, que não forem aprovados pelo Congresso Nacional no rito especial do art. $5^{\circ}, \S 3^{\circ} \mathrm{da}$ $\mathrm{CF} / 88$, têm natureza supralegal: abaixo da Constituição, mas acima de toda e qualquer lei (RAMOS, 2009, p. 244).

A doutrina entende esse fenômeno como um movimento de mão dupla, ocorrendo, assim, tanto um "processo de constitucionalização do Direito Internacional", como um "processo de internacionalização do Direito Constitucional" (PIOVESAN, 2012, p. 69). Desta feita, cria-se um constitucionalismo global tendente a colocar a dignidade da pessoa humana como pressuposto maior e fundante de todas as normas do direito.

Essa recente conjuntura jurídica, com a emergência de um novo paradigma, é que dá sustentação à aplicação, no âmbito interno brasileiro, do controle de convencionalidade e o diálogo entre jurisdições.

Especificamente no Brasil, objeto deste estudo, dois períodos históricos marcam essa virada: o período dos regimes ditatoriais em que se observou um elevado desprezo pelos direitos humanos, contextualizado por uma sociedade desigual e excludente; e o período de instalação do regime democrático a partir de 1988, o qual ainda é incipiente, e convive com a herança dos regimes anteriores. Isso posto, mostra-se recomendável, no atual cenário estatal, explorar o controle de convencionalidade como mecanismo de proteção dos direitos humanos, tendo em vista que o Brasil é um país que ainda suporta o peso da influência de um histórico político autoritário, que culminou no desrespeito a diversos direitos fundamentais.

O presente modelo brasileiro de controle da produção normativa interna, previsto na Constituição, pressupõe uma dupla compatibilização vertical dos atos normativos estatais, ou o chamado "duplo filtro", tendo como paradigma não apenas Constituição Federal, mas também os tratados internacionais de direitos humanos ratificados pelo país.

Para entender essa dupla compatibilização, deve-se analisar, de início, dois dispositivos constitucionais que servirão de base para todo este estudo: o artigo $5^{\circ}$, $\S 2^{\circ}$ e $3^{\circ}$, da CRFB/88. Analisemos um a um:

Art. $5^{\circ}$ Todos são iguais perante a lei, sem distinção de qualquer natureza, garantindo-se aos brasileiros e aos estrangeiros residentes no País a inviolabilidade do direito à vida, à liberdade, à igualdade, à segurança e à propriedade, nos termos seguintes: $[\ldots] \S 2^{\circ}$ Os direitos e garantias expressos nesta Constituição não excluem outros decorrentes do regime e dos princípios por ela adotados, ou dos tratados internacionais em que a República Federativa do Brasil seja parte (BRASIL, 1988).

$\mathrm{O} \S 2^{\circ}$ do artigo $5^{\circ}$ da $\mathrm{CRFB} / 88$ é norma constitucional originária - ou seja, prevista no texto constitucional desde a sua edição original - e traduz uma proposta político-jurídica muito 
clara a respeito da importância dos tratados internacionais de direitos humanos em que o Brasil seja parte.

A supracitada norma fundamenta todo o sistema de controle de convencionalidade, o qual, por conseguinte, existe desde a promulgação da Carta de 1988, ainda que sob outra nomenclatura. Mazzuoli (2013, p. 23) subdivide o supracitado artigo em três partes:
a) Direitos e garantias fundamentais expressos na $\mathrm{CRFB} / 88$;
b) Direitos e garantias fundamentais implícitos ou decorrentes do regime e dos princípios constitucionais;
c) Direitos e garantias provenientes dos tratados internacionais de direitos humanos ratificados pelo Estado brasileiro.

No que tange aos direitos implícitos ou decorrentes da Constituição, é possível aferir, através de uma interpretação teleológica do seu texto considerado no todo, que o princípio internacional pro homine é um princípio orientador de todo o ordenamento jurídico, devendo sempre prevalecer a norma que mais proteja os interesses da pessoa humana.

Ainda na lição de Mazzuoli (2013), desse superprincípio são extraídos outros dois princípios: o da dignidade da pessoa humana, expressamente previsto na Constituição em seu artigo $1^{\circ}$, III; e o da prevalência dos direitos humanos, o qual também pode ser extraído do artigo $4^{\circ}$, II, da CRFB/88. Segundo o autor, o princípio da prevalência dos direitos humanos representa "uma direção política, uma decisão fundamental que deve determinar a atuação do Estado brasileiro em suas relações internacionais. " É uma "limitação material implícita, não podendo ser abolido nem mesmo pela via de Emenda à Constituição" (RAMOS, 2001, p. 274).

Desta feita, e baseando-se na própria Carta Constitucional, havendo conflito entre a Lei Fundamental e um tratado internacional, deve-se aplicar o princípio pro homine ou o da prevalência dos direitos humanos, ambos assegurados pelo artigo $4^{\circ}$, II, da CRFB/88, ou seja, se um tratado internacional vigente contiver maiores garantias relativas a direitos humanos, e havendo conflito aparente entre suas normas e as normas constitucionais, deve prevalecer aquela que melhor atender às necessidades da pessoa humana: "A escolha da norma mais benéfica ao indivíduo é tarefa que caberá fundamentalmente aos Tribunais nacionais e a outros órgãos aplicadores do direito, no sentido de assegurar a melhor proteção possível ao ser humano.” (PIOVESAN, 2010, p. 64)

Isso significa que os referidos tratados podem servir de paradigma para o controle de normas infraconstitucionais. Tal controle, denominado de convencionalidade, difere do controle realizado com base nos tratados comuns, que não versam sobre direitos humanos, os quais, devido ao seu status supralegal, servem de parâmetro para o controle de supralegalidade.

Indo além, ao analisar o artigo $5^{\circ}, \S 2^{\circ}$, da $\mathrm{CRFB} / 88$, pode-se dizer que as convenções internacionais de direitos humanos ratificadas pelo Brasil, quando não incorporadas pelo rito do artigo $5^{\circ}, \S 3^{\circ}$, da CRFB/ 88 , terão status constitucional (não se equiparam a emendas constitucionais, mas tem conteúdo materialmente constitucional), e portanto, servem como parâmetro do controle 
de convencionalidade.

O supracitado dispositivo trouxe grandes mudanças na interpretação do STF sobre a questão dos tratados de direitos humanos. No pioneiro julgamento do Recurso Extraordinário 466.343-1, o ministro Gilmar Mendes, em voto memorável afirmou a tese da supralegalidade dos tratados de direitos humanos. Em suas palavras:

Não se pode negar, por outro lado, que a reforma também acabou por ressaltar o caráter especial dos tratados de direitos humanos em relação aos demais tratados de reciprocidade entre Estados pactuantes, conferindo-lhes lugar privilegiado no ordenamento jurídico. [...] Tudo indica, portanto, que a jurisprudência do Supremo Tribunal Federal, sem sombra de dúvidas, tem de ser revisitada criticamente. [...] Assim, a premente necessidade de se dar efetividade à proteção dos direitos humanos nos planos interno e internacional torna imperiosa uma mudança de posição quanto ao papel dos tratados internacionais sobre direitos na ordem jurídica nacional. É necessário assumir uma postura jurisdicional mais adequada às realidades emergentes em âmbitos supranacionais, voltadas primordialmente à proteção do ser humano. (BRASIL, 2009b, p. 10, 26).

O Habeas Corpus 87.585-8/TO, de 03/12/2008, também teve voto emblemático do Ministro Celso de Mello, que reconheceu o valor constitucional dos tratados de direitos humanos, ainda que não aprovados sob o rito do artigo $5^{\circ}, \S^{\circ}$ (BRASIL, 2009a).

Todavia, esse controle só poderia ser realizado pela via difusa, visto que o controle concentrado estaria reservado apenas para as normas formalmente constitucionais. Pode-se, outrossim, utilizar o Recurso Extraordinário perante o STF, quando a decisão recorrida contrariar dispositivo constitucional, ou, em uma interpretação analógica, quando contrariar qualquer tratado de direitos humanos em vigor no Brasil, considerando-se que esses, por força do artigo $5^{\circ}$, $\S 2^{\circ}$, também detém status materialmente constitucional, apesar de não equivalerem às emendas constitucionais:

Assim, é imperioso entender que quaisquer tratados internacionais de direitos humanos em vigor no Brasil (tenham sido ou não aprovados por maioria qualificada no Congresso Nacional) são paradigma à propositura de recurso extraordinário do STF, sempre que um direito neles previsto tenha sido contrariado por decisão de outro tribunal da qual se pretenda recorrer. O mesmo não ocorre com os instrumentos do controle concentrado de constitucionalidade, a exemplo da ADI ou da ADPF, que somente podem ser manejados relativamente aos tratados internalizados pelo rito do art. $5^{\circ}, \S 3^{\circ}$, da Constituição, não se admitindo sua utilização tendo como fundamento um tratado de apenas status constitucional (nos termos do art. $5^{\circ}, \S 2^{\circ}$ ). (MAZZUOLI, 2013, p. 45).

Assim sendo, se a norma legal foi erigida de acordo com os preceitos atinentes à Constituição de 1988, mas não esteja, do mesmo modo, em conformidade com os tratados de direitos humanos ratificados pelo Brasil, será ela vigente, mas não válida (MAZZUOLI, 2013, p. 7). Isto é, a norma existe no plano jurídico, mas não é capaz de produzir seus efeitos. A vigência está intrinsecamente 
ligada à forma dos atos normativos, enquanto que a validade está relacionada à coerência com as normas hierarquicamente superiores. Aí reside o duplo filtro de controle normativo.

Agora, passemos à análise do que dispõe o artigo $5^{\circ}, \S 3^{\circ}$ :

Art. $5^{\circ}$ Todos são iguais perante a lei, sem distinção de qualquer natureza, garantindo-se aos brasileiros e aos estrangeiros residentes no País a inviolabilidade do direito à vida, à liberdade, à igualdade, à segurança e à propriedade, nos termos seguintes: $[\ldots] \S 3^{\circ}$ Os tratados e convenções internacionais sobre direitos humanos que forem aprovados, em cada Casa do Congresso Nacional, em dois turnos, por três quintos dos votos dos respectivos membros, serão equivalentes às emendas constitucionais (BRASIL, 1988).

$\mathrm{O}$ artigo $5^{\circ}, \S 3^{\circ}$, foi introduzido após a Emenda Constitucional 45/2004, e deu nova roupagem ao instituto do controle de convencionalidade, conferindo-lhe maior abrangência. Ao dar status formalmente constitucional aos tratados de direitos humanos, equiparando-os a emendas constitucionais, quando incorporados sob o procedimento diferenciado das emendas, a norma permitiu a utilização das ações do controle concentrado tendo como parâmetro as convenções internacionais de direitos humanos que se enquadrem nessas exigências.

Essa forma de controle, entretanto, ainda não pode usar como parâmetro a Convenção Americana de Direitos Humanos, já que essa não assumiu o rito de uma emenda constitucional, não sendo considerada formalmente constitucional. Tratados desse tipo só podem servir de parâmetro para o controle difuso de convencionalidade.

Agora, é possível entender como funcionam os dois níveis de controle inicialmente referidos neste tópico: doravante, todas as normas infraconstitucionais deverão passar por dois níveis de aprovação para ter validade jurídica: em primeiro lugar, a Constituição (controle de constitucionalidade) e as convenções de direitos humanos ratificadas pelo Estado brasileiro, sejam elas equiparadas ou não a emendas constitucionais (controle de convencionalidade); em segundo lugar, os tratados internacionais comuns (controle de supralegalidade).

Vale ressaltar que, no caso de confronto de lei doméstica com tratado internacional de direitos humanos, se a lei for anterior à ratificação do tratado, ela será revogada, visto que o tratado lhe é posterior e hierarquicamente superior. Sendo o inverso, ou seja, se a norma interna for posterior ao tratado internacional, ela será inválida e ineficaz.

Cabe tanto aos órgãos do Poder Judiciário interno, bem como aos Tribunais internacionais criados por convenções entre os Estados, o exercício do controle de convencionalidade. Quanto a isso, é pacífico o entendimento de que para realizar esse controle, os tribunais internacionais não necessitam de qualquer autorização estatal, visto que o país que a ele esteja subordinado, se comprometeu, através de convenção, no livre exercício de sua soberania. Os tratados internacionais passam a ter "eficácia paralisante [...] das demais espécies normativas domésticas [...]" (MAZZUOLI, 2013, p. 33). Ademais disso, as cortes internacionais têm função suplementar e somente intervirão quando houver flagrante omissão ou insuficiência do Poder Judiciário de 
origem.

\section{2 O controle de convencionalidade realizado pela corte interamericana de direitos humanos}

O processo de redemocratização do Brasil está intimamente ligado ao processo de incorporação de relevantes instrumentos internacionais de proteção dos direitos humanos. Dentre eles, um dos mais relevantes foi a ratificação da Convenção Americana de Direitos Humanos, a qual criou a Corte Interamericana de Direitos Humanos (Corte IDH).

No âmbito do sistema interamericano, a Convenção Americana de Direitos Humanos, ou Pacto de São José da Costa Rica, é considerada o diploma de maior relevância. O Estado brasileiro foi o que mais tardiamente aderiu à Convenção, fazendo-o apenas em 1992. A Corte Interamericana, contudo, só teve sua competência reconhecida pelo Brasil a partir 1998.

Admitindo a jurisdição da Corte, o Estado brasileiro passou a se submeter ao monitoramento internacional acerca de possíveis violações aos direitos fundamentais em seu território. Desta feita, o Estado consentiu o controle e a fiscalização do referido órgão internacional, quando as instituições nacionais se tornarem omissas na tarefa de zelar pela preservação dos direitos fundamentais dos indivíduos. Repise-se, entretanto, que a ação internacional é sempre uma ação de caráter suplementar, em relação à atuação dos órgãos internos dos Estados-partes.

A adesão a uma Corte Internacional já havia sido prevista no texto constitucional, ao consagrar o primado do respeito aos direitos humanos como princípio norteador da ordem jurídica:

[...] a Lei Suprema brasileira, a Constituição Federal, não é hostil a tribunais internacionais e em consequência disto não repele a responsabilização internacional do Estado brasileiro por violação de seus compromissos internacionais. De fato, o art. $7^{\circ}$ do Ato das Disposições Constitucionais Transitórias estabelece o oposto, isto é, que o Brasil deve favorecer a criação de um Tribunal internacional de direitos humanos. Além disso, o art. $4^{\circ}$ do corpo permanente da Constituição estabelece que a prevalência dos direitos humanos é princípio diretivo do Brasil em suas relações internacionais. Finalmente, dispõe o art. $5^{\circ}, \S 2^{\circ}$, que os direitos e garantias expressos na Constituição não excluem outros decorrentes dos tratados internacionais em que o Brasil seja parte (RAMOS, 2001, p. 502-503).

Essa inovação jurídica, trazida pela $\mathrm{CRFB} / 88$, lança uma nova interpretação sobre os conceitos de soberania nacional e não intervenção, levando à flexibilização e relativização desses valores (PIOVESAN, 2010, p. 74). Ao verificar a ocorrência de violação aos direitos humanos tutelados na Convenção Americana, a Corte IDH poderá tomar as seguintes atitudes: condenar o Estado em obrigação de fazer para reparar e prevenir o dano, e/ou condenar o Estado a pagar indenização, equivalendo, nesse caso, a um título executivo.

Essa decisão da Corte é dotada de força jurídica vinculante, sendo de observância 
obrigatória pelo Estado, cabendo a esse o seu imediato cumprimento. Não há relação de hierarquia entre os tribunais nacionais e internacionais, razão pela qual não há necessidade de reforma interna da decisão nacional, pois as instâncias internacionais apenas condenam o Estado infrator a reparar o dano causado.

Em relação à execução da sentença internacional, a Corte Interamericana de Direitos Humanos estipula que a cada Estado cabe escolher a melhor forma, de acordo com seu direito interno, de executar os comandos da Corte. Entretanto, o artigo 68.2 da Convenção Americana inova determinando que se utilize as regras internas de cada país para executá-lo, no que tange à parte indenizatória da sentença da Corte.

No que concerne às outras medidas reparatórias de caráter não pecuniário, estas dependerão exclusivamente de mecanismos internos para sua efetividade, tendo em vista que a sentença internacional seria meramente declaratória.

A supervisão do cumprimento das sentenças da Corte fica a cargo da mesma, bem como dos Estados-partes que sofreram a reprimenda. O que se percebe na prática é que, no que se refere às cláusulas de obrigação de fazer, por se tratarem de institutos meramente declaratórios, há um elevado grau de descumprimento dos Estados condenados, principalmente quando se trata de determinação de investigação de criminosos políticos, como é o caso dos crimes ocorridos na ditadura militar brasileira.

Além da Convenção Americana de Direitos Humanos, o sistema interamericano incorporou outras novas Convenções setoriais. São de muita relevância as disposições de duas dessas Convenções setoriais, quais sejam a Convenção Interamericana para Prevenir e Punir a Tortura e a Convenção Interamericana sobre o Desaparecimento Forçado de Pessoas.

A primeira delas foi introduzida no ordenamento jurídico brasileiro com o Decreto Legislativo 98.386/1989 e estabelece a responsabilidade individual pelo delito de tortura e os deveres estatais para prevenir e punir a tortura no âmbito de sua jurisdição (BRASIL, 1989). A tortura, a partir desse instrumento normativo, passou a ser considerada crime contra a ordem internacional, para, assim, transferir aos Estados-partes uma maior pressão no intuito de prevenir e investigar tais atos.

Esta medida se justifica ao tempo em que a prática de tortura "revela a perversidade do Estado que de garantia de direitos passa a ter em seus agentes brutais violadores de direitos" (PIOVESAN, 2007, p. 203-204).

Já a Convenção Interamericana sobre o Desaparecimento Forçado de Pessoas foi inserida na ordem jurídica brasileira através do Decreto Legislativo $n^{\circ} 8.766 / 2016$. Ela consagra o princípio da responsabilidade individual no delito de desaparecimento forçado, tanto para seus perpetradores, como para o Estado (BRASIL, 2016), e estabelece como consequências jurídicas da tipificação desse delito internacional as seguintes:

[...] jurisdição universal e obrigação de extraditar ou julgar os responsáveis do delito; obrigação de não outorgar asilo político aos responsáveis pelo delito; imprescritibilidade da ação; obrigação dos Estados de investigar e punir os 
responsáveis pelo delito; inadmissibilidade da eximente de obediência devida às ordens superiores; e improcedência de se beneficiar da condição de membro do Poder Executivo ou Legislativo, de que possa resultar a impunidade pelos atos constitutivos do desaparecimento forçado de pessoas (TRINDADE, 2000, p. 141, grifo nosso).

A doutrina é uniforme a respeito da obrigatoriedade de investigação por parte dos Estados dos delitos de desaparecimento forçado, bem como confirmam o seu traço de imprescritibilidade, devido ao seu caráter permanente. Contudo, no Brasil, o que se observa concretamente é a impunidade desses delitos, quando praticados por agentes estatais durante o regime da ditadura militar.

\section{ANÁLISE DA VALIDADE DA LEI DE ANISTIA BRASILEIRA SOB O PRISMA DO DUPLO FILTRO OU DUPLO CONTROLE}

Como já apontado, a Convenção Americana de Direitos Humanos estabelece parâmetros protetivos mínimos relativos aos direitos humanos, dentre eles: direito a não ser submetido à tortura; direito à justiça ou a proteção judicial; direito à verdade; o direito à prestação jurisdicional efetiva. Esses constituem o núcleo inderrogável de direitos a serem protegidos em tempos de guerra, instabilidade, comoção pública ou calamidade pública.

Além da Convenção, muitos outros instrumentos internacionais têm convergido para a mesma direção de tratar a proibição de tortura como um direito absoluto, inderrogável, a exemplo da Convenção Europeia de Direitos Humanos e a própria Convenção Contra a Tortura, já citada.

Considerando cada um desses parâmetros, percebe-se que anistia concedida aos criminosos políticos da ditatura militar brasileira (lei $\mathbf{n}^{\mathbf{0}}$ 6.683/79) viola a todos. Principalmente, ela nega ao povo brasileiro o direito a conhecer a verdade histórica, isentando o Estado de reparar os danos causados por ele próprio a inocentes, impedindo, igualmente, a investigação dos culpados. A Corte Interamericana de Direitos Humanos, a qual, repise-se, o Brasil aderiu irrestritamente, é taxativa a respeito da completa invalidade de leis de anistia como a brasileira:

A Corte Interamericana realçou que leis de anistia são incompatíveis com a Convenção Americana de Direitos Humanos e são considerados ilícitos internacionais. A sua revogação não é uma forma de interferir no direito interno do país e afetar a sua soberania, mas sim uma reparação não pecuniária às vítimas (PIOVESAN, 2010, p. 459).

A experiência de outros países membros do sistema interamericano, como a Argentina, mostra uma plena incorporação da jurisprudência da Corte IDH. A política de acesso à verdade e à justiça em outros países latino-americanos é muito mais ampla e eficiente do que no Brasil. Já há precedentes de Sentenças da Corte IDH que foram adotadas pelo Poder Judiciário na Argentina, Chile, Peru, Uruguai e Colômbia, todos decidindo pela incompatibilidade de suas leis de anistia, 
similares à do Brasil. O Brasil é, portanto, o único Estado latino-americano em que uma lei de anistia foi julgada válida pelo Poder Judiciário.

Desta feita, é imprescindível que o Estado brasileiro adote políticas para viabilizar uma justiça de transição que possa "romper com o passado autoritário e viabilizar o ritual de passagem para a ordem democrática." (PIOVESAN, 2010, p. 465-468).

O período da ditadura militar no Brasil, entre os anos de 1964 a 1985, deixou uma tenebrosa sombra em nossa história recente. Muitas foram as atrocidades cometidas pelo Estado. A maioria delas tem sido, todavia, relegada ao esquecimento e à impunidade. Hodiernamente, muitos segmentos da sociedade civil e até alguns setores do Poder Público lutam para que a justiça seja realizada, e que os diversos casos de tortura, desaparecimento forçado, e demais crimes políticos perpetrados à época, sejam devidamente esclarecidos e seus malfeitores, enfim, punidos.

Em 1995, a lei 9.140/95 criou a Comissão Especial sobre Mortos e Desaparecidos Políticos, a qual reconheceu oficialmente 362 casos de opositores políticos assassinados ou desaparecidos durante o regime militar. Já a Secretaria Especial de Direitos Humanos, do Ministério da Justiça, em relatório intitulado "Direito à memória e à verdade" (BRASIL, 2007), informou um número de 475 pessoas naquelas condições. Há estimativas de que cerca de 50.000 pessoas foram presas por questões políticas e, grande parte, torturadas. A conhecida Operação Condor, da qual o Brasil participou, associado a outros países da América Latina, aplicou uma política terrorista responsável por 60.000 mortes de opositores políticos em todos os países participantes.

São mais de trinta anos de mobilização em torno desse tema, ainda muito controvertido juridicamente. A lei de anistia $n^{\circ} 6.683 / 79$ tem servido, durante todo esse tempo, de escudo protetor para os infratores, obstruindo o acesso à verdade e à justiça.

No relatório do MPF, intitulado "Justiça de Transição" (2011-2013), estão registradas as dificuldades desse órgão em empreender as ações penais contra os responsáveis pelas atrocidades do período ditatorial.

O Poder Legislativo, por sua vez, permanece omisso em tipificar adequadamente o crime de desaparecimento forçado, mesmo após expressa determinação da Corte Interamericana de Direitos Humanos.

A deputada Luiza Erundina, em 2011, apresentou PL no 573/2011, sugerindo mudança de interpretação ao artigo $1^{\circ}$ da lei de anistia, em conformidade com as disposições da Corte. Tal projeto tem sido rechaçado nas Comissões parlamentares até então, estando, contudo, pendente de votação definitiva. Projeto de Lei análogo tramita no Senado Federal (n 237/2013), proposto pelo Senador Randolfe Rodrigues, ainda sem conclusão.

Com relação à própria lei de anistia, considerada em sua íntegra, muitas são as discussões a respeito de sua validade normativa. A lei $n^{\circ} 6.683 / 79$, foi criada antes do advento da Constituição Federal de 1988, e da adesão pelo Brasil à Convenção Americana de Direitos Humanos e à Corte Interamericana de Direitos Humanos.

Em seu artigo $1^{\circ}$, a lei assim dispõe: 
Art. $1^{\circ}$ É concedida anistia a todos quantos, no período compreendido entre 02 de setembro de 1961 e 15 de agosto de 1979, cometeram crimes políticos ou conexo com estes, crimes eleitorais, aos que tiveram seus direitos políticos suspensos e aos servidores da Administração Direta e Indireta, de fundações vinculadas ao poder público, aos Servidores dos Poderes Legislativo e Judiciário, aos Militares e aos dirigentes e representantes sindicais, punidos com fundamento em Atos Institucionais e Complementares (BRASIL, 1979, grifo nosso).

Pelo exposto, poderia se concluir que, tendo os efeitos da lei de anistia incidido apenas aos crimes "no período compreendido entre 02 de setembro de 1961 e 15 de agosto de 1979", sua eficácia haveria se exaurido, antes mesmo da ratificação da Convenção Americana de Direitos Humanos, e, portanto, não caberia a análise de compatibilidade em relação a esta. Nada obstante, considerando que os crimes de desaparecimento forçado, como os perpetrados na época da ditadura militar, e anistiados pela referida lei, têm, na verdade, o caráter permanente, temos o seguinte impasse:

a) deve ser afastada a incidência da lei de anistia referente a esses crimes, visto que a eficácia legal já se exauriu, tendo produzido efeitos tão somente sobre aqueles crimes não permanentes cometidos no período de sua abrangência. Quanto aos crimes permanentes, esses continuam ocorrendo (não houve interrupção do ato delitivo), pois seus efeitos não cessam até que se localizem os corpos das vítimas desaparecidas. Assim sendo, não podem ser alcançados mais pelos efeitos da lei de anistia, já exaurida; ou,

b) partindo-se do pressuposto de que a lei de anistia continua válida e produzindo seus efeitos, o que justificaria a recusa do Poder Público em processar e julgar os infratores, deve-se considerar, então, que a lei de anistia foi revogada pela Convenção que lhe é posterior e superior, não cabendo, do mesmo modo, que se coloque tal norma como empecilho para a investigação dos ilícitos.

Consequentemente, fica evidenciado o caráter contraditório do posicionamento do Poder Público em face da admissão da lei de anistia no ordenamento jurídico pátrio. É premente a necessidade de mudança nesse entendimento, principalmente por parte dos Tribunais brasileiros, que tem oferecido muita resistência nesse sentido.

Hoje, há grande controvérsia na esfera Judiciária quanto à validade de leis de anistia. A essas divergências hermenêuticas, some-se o forte apelo social para a punição dos agentes civis e militares responsáveis pelos crimes perpetrados no regime ditatorial. Com o processo de redemocratização do Brasil em 1988, a ruptura com o regime autoritário antes instalado fez nascer muitos impasses quanto ao modo pelo qual seria feita a transição entre momentos históricos tão antagônicos.

O Brasil já sofreu condenações da Corte IDH pela sua postura omissa quanto à resolução desta problemática. A conduta do Judiciário, pode-se dizer, chega a ser conivente com a impunidade nesse caso. Em 2008, a OAB protocolou a ADPF 153/DF no Supremo Tribunal Federal questionando a validade da lei de anistia $n^{\circ} 6.683 / 79$ frente à Constituição de 1988. O STF 
decidiu pela recepção da referida lei sob os argumentos de que sua promulgação se deu em um momento histórico no qual a sociedade desejava esquecer o passado e seguir em frente. Seria uma medida política, sobre a qual não caberia ao Judiciário realizar um juízo de valor (BRASIL, 2010).

Cabe aqui, antes de tudo, ressaltar que há, como em qualquer debate jurídico desta monta, posições divergentes, havendo aqueles que compreendem ser a decisão do Supremo razoável para o caso em apreço. Os filiados a esse pensamento sustentam argumentos diversos, como a garantia de segurança jurídica em face de um momento de transição política que acarreta instabilidade institucional por natureza; ou por ser a anistia resultado de uma conciliação nacional rumo a uma transição pacífica entre regimes; ou mesmo como forma de evitar a promoção de vingança social sobre questão já esquecida, o que beiraria ao anacronismo jurídico (COELHO; MANSO, 2012, p. 19). Em todos os casos, pode-se resumir a defesa em prol da validade da lei anistiadora em um argumento unificador, qual seja, a conclusão de um processo de transição democrática que demandou acordos vis para estabelecer uma passagem "madura" e "pacífica" entre regimes.

Diametralmente oposta a tal compreensão, há corrente de pensamento que se mantem resistente a tal raciocínio jurídico, ao qual aqui se filia o presente trabalho. Sob esse viés considerase que o entendimento do STF desaguou em impunidade, conivência com a violação dos direitos fundamentais e retrocesso democrático.

A despeito da resistência, a realidade é que a decisão do processo objetivo e a interpretação dada pela Corte Suprema, a qual tem a última palavra sobre questões afetas à Carta Magna, sob o prisma do controle de constitucionalidade, resultou em doravante se considerar a lei anistiadora como compatível com o atual sistema jurídico e recepcionada pela ordem constitucional. Todavia, o mesmo não se pode dizer quanto à sua convencionalidade, como veremos em breve.

Anteriormente a isso, em 1997, foi submetido à Comissão Interamericana o caso Gomes Lund versus Brasil, também conhecido como o caso da Guerrilha do Araguaia, referente ao desaparecimento de mais de vinte integrantes da aludida Guerrilha na década de setenta, durante as operações militares que se sucederam na região. Após a admissão do caso, em 06 de março de 2001, e apresentação do relatório, em 31 de outubro de 2008, ante a negativa do Estado Brasileiro, em prestar as informações que lhe foram solicitadas, a Comissão submeteu-o à jurisdição da Corte, para fins de se esclarecerem os conflitos existentes entre as leis de anistia e o desparecimento forçado de pessoas, bem assim, as violações aos direitos humanos que o caso "Guerrilha do Araguaia" registrava.

O Estado Brasileiro requereu o arquivamento do feito, alegando dentre outros argumentos, a incompetência da Corte para analisar o caso, vez que o Brasil havia ratificado a Convenção Americana de Direitos Humanos após a ocorrência dos referidos crimes, não podendo as normas da Convenção incidirem sobre esses fatos pretéritos, em nome da legalidade.

Todavia, o governo brasileiro não observou que os fatos envolvendo o desaparecimento forçado de pessoas, constituem, no âmbito do direito penal, em um tipo similar ao de sequestro, e, sendo assim, sua consumação se prolonga no tempo, já que é um crime permanente. 
Desta maneira, essa e as demais defesas do Estado brasileiro caíram por terra, culminando na condenação por unanimidade do Brasil, em 24 de novembro de 2010, perante a Corte Interamericana de Direitos Humanos.

Para a Corte, as disposições da lei da anistia que impedem a investigação e a sanção a graves violações de direitos humanos são incompatíveis com a Convenção Americana e não podem permanecer como obstáculo para a investigação dos fatos, nem para a identificação e punição dos responsáveis.

Declarou, ademais, a Corte que o STF não exerceu o necessário controle de convencionalidade posteriormente à sentença da ADPF 153/DF, mesmo após a interposição dos embargos de declaração pela $\mathrm{OAB}$, os quais ainda aguardam julgamento.

A sentença declarou que o Estado brasileiro é responsável pelo desaparecimento forçado e, portanto, pela violação dos direitos ao reconhecimento da personalidade jurídica, à vida, à integridade pessoal e à liberdade pessoal das pessoas indicadas na decisão. Foi então determinado que o Brasil deve proceder às investigações penais, determinar o paradeiro das vítimas e entregar seus restos mortais às famílias. Além disso, deve o país realizar ato público de responsabilidade pelos fatos e indenizar as vítimas ou suas famílias, dentre outras determinações.

A condenação brasileira no caso Gomes Lund terminou se tornando um marco em matéria de controle de convencionalidade, provocando rupturas no sistema jurídico brasileiro:

O caso Gomes Lund constitui, nesse contexto, um paradigma de tensão entre os dispositivos internacionais e o direito interno após a decisão do STF na ADPF $n^{\circ} 153$ em 2010. A sentença do caso Gomes Lund declarou os crimes de desparecimento forçado praticado pelo Estado brasileiro como grave violação de direitos humanos, insuscetível de anistia (ANTUNES, 2017, p. 169).

Passados anos desde essa emblemática decisão, e não se tendo observado qualquer evolução do Brasil no que tange ao cumprimento dos pontos resolutivos da sentença internacional na qual foi condenado, o supramencionado partido PSOL impetrou, em 2014, a ADPF n 320/DF, que ainda tramita no Supremo Tribunal Federal.

A nova contenda judicial visa questionar a validade da Lei de Anistia não mais sob o paradigma do texto constitucional, o qual já foi discutido e decidido por aquela Corte, mas sim sob o parâmetro da compatibilidade com a Convenção Interamericana de Direitos Humanos, em um controle de convencionalidade que deverá ser realizado agora, pelo próprio Estado, através do seu Judiciário (BRASIL, 2014). Aguardemos o desfecho de mais esse capítulo tortuoso da história constitucional brasileira.

A realidade é que, para facilitar a transição entre os regimes ditatorial e democrático, a 
Carta de 1988 adotou textos constitucionais abertos, carregados de normas e princípios de elevado teor axiológico. O que em parte facilitou, de fato, a implementação de diversas mudanças positivas na cultura jurídica, mas que também concedeu aos Poderes Públicos a possibilidade de manusear o texto constitucional com certa flexibilidade, preservando interesses da elite dominante do regime anterior.

Mas não se pode mais negar que a Carta Magna privilegia a dignidade humana como valor supremo. A intenção do legislador constituinte originário está estampada em seu texto. Além disso, $\mathrm{o}$ artigo $5^{\circ}, \S 1^{\circ}$, da CRFB/88 atribuiu força normativa e aplicabilidade imediata a todos esses preceitos constitucionais, cabendo aos Poderes Públicos garantirem a eficácia máxima a todos os direitos e garantias fundamentais. Um desses preceitos é o da prevalência dos direitos humanos, que foi instituído como princípio a reger o Brasil nas suas relações internacionais, mas que a elas não se limita, emanando, igualmente, na ordem jurídica interna.

Assim, quando se trata de crimes contra a humanidade, o princípio da dignidade humana incide categoricamente. Desta maneira, a cogência do princípio da dignidade humana faz pressupor o justificado repúdio aos crimes contra a humanidade. Os direitos à memória e à verdade histórica são inderrogáveis e pertencem ao povo, enquanto uma unidade que constitui a nação. São direitos de incontestável magnitude para a pacificação social e construção de uma sólida e madura democracia. Não podem ser manipulados por interpretações legais duvidosas e tendenciosas conferidas pelos Poderes estatais.

No Brasil, há ainda certa confusão quanto à amplitude do direito à memória, especialmente. Os defensores da anistia são, em geral, contrários às ações governamentais em prol da memória e da verdade, por acreditar que a garantia de tais direitos implica necessariamente na possibilidade de persecução penal da conduta de tais agentes. Contudo, o direito à memória e à verdade implica em conhecer dos fatos tais como ocorreram, independentemente da desejada punição criminal. A persecução penal e a investigação acerca dos fatos ocorridos têm relação, mas não são sinônimos, sendo que a primeira pressupõe a segunda, mas a segunda não necessariamente origina a segunda.

É impensável a fragilização de tais direitos, sendo ônus do Estado e função do Judiciário nesta disputa é a de promover o maior alcance possível às normas de direitos humanos, tanto daquelas constantes no texto constitucional como direitos fundamentais, como também das previstas nos tratados aos quais o país se obrigou perante a comunidade internacional. Do contrário, perderá duplamente o povo brasileiro, por não poder finalmente vislumbrar a Justiça se concretizando, e por se ver desmoralizado e desacreditado frente os demais Estados soberanos com os quais havia se comprometido.

\section{CONSIDERAÇÕES FINAIS}

É evidente que a Constituição brasileira de 1988 é referência de democracia e de positivação dos direitos humanos, na figura dos direitos fundamentais, nunca antes observada na história jurídica de nosso país, inclusive no que concerne à previsão de submissão a uma Corte 
Internacional de Direitos Humanos. Isso representa a modernização do sistema jurídico, e a inserção pátria na ordem jurídica externa, movimento extremamente necessário à garantia eficaz dos direitos humanos. Além disso, o sistema internacional de proteção dos direitos humanos representa uma conquista atingida penosamente nesse país, que não pode ser mitigada ou derrogada.

O sistema interamericano tem se mostrado um importante mecanismo de proteção dos direitos humanos para suprir a omissão das instituições nacionais da América Latina no seu dever de proteção do indivíduo, pressionando os governos para que tomem providências efetivas no combate aos crimes de lesa-humanidade.

Além disso, a publicização internacional das violações de direitos humanos conferidas pelas sentenças da Corte IDH são um eficaz instrumento de coerção ao Estado infrator, que fica sujeito ao risco de constrangimento político e moral, por parte dos demais Estados, o que é mais um estímulo para que as mudanças ocorram.

Entretanto, ainda é um sistema precário e, por vezes, ignorado por motivações políticas ou por exegeses ultrapassadas. A evidência disso é o desrespeito institucional brasileiro frente às orientações da Corte IDH sobre a invalidade da lei de anistia ${ }^{\circ} 6.683 / 79$, a qual, indubitavelmente, fere valores caros à nossa sociedade, fragilizando a soberania popular.

Para haver o implemento efetivo de todos os benefícios oriundos da adesão do país aos diplomas de proteção internacional dos direitos humanos, não se pode mais admitir que o Brasil ratifique tratados acerca dessa matéria e, simplesmente, se recuse a aceitar um aparato normativo internacional de garantia, implementação e fiscalização dos direitos garantidos nesses instrumentos, ao qual ele próprio se submeteu livremente. Superar esse impasse é fundamental à plena e integral proteção dos direitos humanos no âmbito nacional.

Por fim, saliente-se que essas ações são essenciais para a efetiva inserção do Brasil no cenário internacional de proteção dos direitos humanos. Pois, a despeito dos enormes avanços da nação a caminho da efetiva implantação de uma respeitável democracia, a verdade é que ainda há muitos obstáculos a serem transpostos. Não é possível se afirmar que existe verdadeiramente uma democracia, quando todo o povo sofre nas mãos de um Estado impune. Afinal, o valor mais caro a um Estado de Direito é a ideia de que ninguém está acima da lei, e nessa ideia se inclui o próprio Estado e seus agentes.

\section{REFERÊNCIAS}

ANTUNES, Fernando Luis Coelho. O controle de convencionalidade e as transformações no constitucionalismo contemporâneo: a ADPF 153 e a decisão da corte interamericana de direitos humanos no Caso Gomes Lund. Revista do Direito Público, Londrina, v. 12, n. 3, p. 153-190, dez. 2017. Doi: 10.5433/1980-511X2017v12n3p153. Disponível em: http://www.uel.br/revistas/ uel/index.php/direitopub/article/view/28074/22686. Acesso em: 30 jul. 2018.

BRASIL. [Constituição (1988)]. Constituição da República Federativa do Brasil de 1988. 
Brasília: Presidência da República, 1988. Disponível em: http://www.planalto.gov.br/ccivil_03/ constituicao/constituicaocompilado.htm. Acesso em: 12 jun. 2018.

BRASIL. Arguição de Descumprimento de Preceito Fundamental no 320/DF. Interessados: Presidente da República e Congresso Nacional. Relator: Ministro Luiz Fux. Brasília, 28 ago. 2014. Disponível em: http://redir.stf.jus.br/estfvisualizadorpub/jsp/consultarprocessoeletronico/ ConsultarProcessoEletronico.jsf?seqobjetoincidente=4574695. Acesso em: 7 jun. 2018.

BRASIL. Decreto $\mathbf{n}^{\mathbf{0}} 8.766$ de 30 de março de 2016. Promulga a Convenção Interamericana sobre o Desaparecimento Forçado de Pessoas, firmada pela República Federativa do Brasil, em Belém, em 10 de junho de 1994. Brasília: Presidência da República, 2016. Disponível em: http:// www.planalto.gov.br/ccivil_03/_ato2015-2018/2016/decreto/D8766.htm. Acesso em: 25 jun. 2018.

BRASIL. Decreto n 98.386 de 09 de novembro de 1989. Promulga a Convenção Interamericana para prevenir e punir a tortura. Brasília: Presidência da República, 1989. Disponível em: http://pfdc.pgr.mpf.mp.br/atuacao-e-conteudos-de-apoio/legislacao/tortura/ dec_98386_89.pdf. Acesso em: 2 jun. 2018.

BRASIL. Habeas Corpus no 87.585-8/TO. Relator: Ministro Marco Aurélio, Tribunal Pleno, julgado em: 3 dez. 2008, DJE-118, divulg. 25 jun. 2009, public. 26 jun. 2009, ement. 2366-2. São Paulo, 2009a. Disponível em: http://redir.stf.jus.br/paginadorpub/paginador. jsp?docTP=AC\&docID=597891. Acesso em: 30 mai. 2018.

BRASIL. Lei $\mathbf{n}^{0} \mathbf{6 . 6 8 3}$ de 28 de agosto de 1979. Concede anistia e dá outras providências. Brasília: Presidência da República, 1979. Disponível em: http://www.planalto.gov.br/CCivil_03/ leis/L6683.htm. Acesso em: 4 jun. 2018.

BRASIL. Recurso Extraordinário no 466.343-1. Relator: Ministro Cezar Peluso, Tribunal Pleno, julgado em: 3 dez. 2008, DJE-104, divulg. 4 jun. 2009, public. 05 jun. 2009, ement. 2363-6. São Paulo, 2009b. Disponível em: http://redir.stf.jus.br/paginadorpub/paginador. jsp?docTP=AC\&docID=595444. Acesso em: 05 mai. 2018.

BRASIL. Secretaria Especial dos Direitos Humanos. Direito à verdade e à memória: Comissão Especial sobre Mortos e Desaparecidos Políticos. Brasília: Secretaria Especial dos Direitos Humanos, 2007. Disponível em: http://www.dhnet.org.br/dados/livros/a_pdf/livro_memoria1_ direito_verdade.pdf. Acesso em: 9 jul. 2018.

BRASIL. Supremo Tribunal Federal. Arguição de Descumprimento de Preceito Fundamental $n^{\mathbf{0}}$ 153/DF. Relator: Ministro Eros Grau, Tribunal Pleno, julgado em 29 abr. 2010, DJE-145, divulg. 5 ago. 2010, public. 06/08/2010, ement. 02409-01. Disponível em: http://redir.stf.jus.br/ paginadorpub/paginador.jsp?docTP=AC\&docID=612960. Acesso em: 16 jul. 2018.

COELHO, Saulo de Oliveira Pinto; MANSO, Renata de Almeida. Duplo Controle Constitucional-Convencional de Legitimidade da Lei de Anistia: reflexões sobre a jurisdição constitucional de transição e as relações entre anistia e memória no contexto da redemocratização brasileira. In: EILBAUM, Lucia; LEAL, Rogério Gesta; MEYE Samantha Ribeiro (coord.).

Justiça de transição: verdade, memória e justiça. Florianópolis: FUNJAB, 2012. p. 361-390. Disponível em: http://www.publicadireito.com.br/artigos/?cod=e84401ad27c4cfb9. Acesso em: 11 fev. 2019. 
COMISSÃO INTERAMERICANA DE DIREITOS HUMANOS. Convenção Americana sobre Direitos Humanos. San José, Costa Rica, nov. 1969. Disponível em: https://www.cidh.oas.org/ basicos/portugues/c.convencao_americana.htm. Acesso em: 17 jul. 2018.

MAZZUOLI, Valerio de Oliveira. Teoria geral do controle de convencionalidade no direito brasileiro. In: MARINONI, Luiz Guilherme; MAZZUOLI, Valerio de Oliveira (coord.). Controle de convencionalidade: um panorama latino-americano: Brasil, Argentina, Chile, México, Peru, Uruguai. Brasília, DF: Gazeta Jurídica, 2013, p. 3-56.

PIOVESAN, Flávia. Direitos humanos e diálogo entre jurisdições. Revista Brasileira de Direito Constitucional - RBDC, São Paulo, n. 19, jan./jun. 2012.

PIOVESAN, Flávia. Direitos humanos e o direito constitucional internacional. 8. ed. São Paulo: Saraiva, 2007.

PIOVESAN, Flávia. Temas de direitos humanos. 4. ed. São Paulo: Saraiva, 2010.

RAMOS, André de Carvalho. Direitos humanos em juízo. São Paulo: Ed. Max Limonade, 2001.

RAMOS, André de Carvalho. Supremo Tribunal Federal brasileiro e o controle de convencionalidade: levando a sério os tratados de direitos humanos. Revista da Faculdade de Direito da Universidade de São Paulo, São Paulo, v. 104, p. 241-286, jan./dez. 2009.

TRINDADE, Antônio Augusto Cançado. O sistema interamericano de direitos humanos no limiar do novo século: recomendações para o fortalecimento de seu mecanismo de proteção. In: GOMES, Luiz Flavio; PIOVESAN, Flávia. O sistema interamericano de proteção dos direitos humanos e o direito brasileiro. São Paulo: Editora Revista dos Tribunais, 2000.

Como citar: RODRIGUES, Thaise Silva; BRAGA, Romulo Rhemo Palitot; COELHO; Ana Christina Soares Penazzi. Controle de convencionalidade da Lei de Anistia $n^{\circ}$ 6.683/79: Direito à memória e à verdade. Revista do Direito Público, Londrina, v. 14, n. 3, p. 131-149, dez. 2019. DOI: $10.5433 / 24157-108104-1.2019 v 14 n 3 p .131$. ISSN: 1980-511X

Recebido em: 02/08/2018

Aprovado em: 13/02/2019 